\title{
Streptococcus dysgalactiae (Diernhofer) nom. rev.
}

\author{
ELLEN I. GARVIE, J. A. E. FARROW, AND A. J. BRAMLEY* \\ National Institute for Research in Dairying, Shinfield, Reading, England
}

\begin{abstract}
Streptococcus dysgalactiae did not appear on the Approved Lists of Bacterial Names in 1980. This species is frequently isolated from milk and is well known as a cause of bovine mastitis. Deoxyribonucleic acid-deoxyribonucleic acid hybridization has shown that it is a species which is distinct from other species found in the same habitat. We propose that Streptococcus dysgalactiae be revived and recognized as a species, with NCDO 2023 as the type strain.
\end{abstract}

Streptococcus dysgalactiae (Diernhofer) lost standing in nomenclature when it was omitted from the Approved Lists of Bacterial Names (13). The reason for this omission is not known, but it may have happened because no type strain was designated before 1980; alternatively, the omission may simply have been an oversight. $S$. dysgalactiae is well known to veterinarians as a frequent cause of bovine mastitis (10). However, detailed studies of the properties of this organism are not available, and little work has been done since the early descriptions of Diernhofer (2), Edwards (3), and Plastridge and Hartsell (11). Recent work (5-7), including deoxyribonucleic acid(DNA)-DNA hybridization and a study of the lactate dehydrogenase, has shown that $S$. dysgalactiae is a distinct species. Therefore, we propose that the name of this species be revived in accordance with Rule 28A (9) as Streptococcus dysgalactiae nom. rev.

In Bergey's Manual of Determinative Bacteriology, 8th ed., Deibel and Seeley (1) indicate that streptococci from bovine mastitis and streptococci from polyarthritis in lambs have been called $S$. dysgalactiae; however, there are properties that distinguish strains from these two sources. The following description is based on strains from bovine mastitis.

Streptococcus dysgalactiae (dys.ga.lac'ti.ae. Gr. pref. dys ill, hard; Gr. n. galactia pertaining to milk; N. L. n. dysgalactia loss or impairment of milk secretion, dysgalactia; N. L. gen. n. dysgalactiae of dysgalactia). Gram-positive cocci or oval cells in short- to medium-length chains. The cell wall peptidoglycan contains $L^{-}$ Lys-L-Ala linkage (12). Growth in glucose nutrient broth is poor and has a final pH of 4.7 to 4.9. On blood agar plates colonies are surrounded by a wide zone of alpha hemolysis (greening).

The optimum temperature for growth is $37^{\circ} \mathrm{C}$. Growth does not occur at 10 or $45^{\circ} \mathrm{C}$, in $6.5 \%$ $\mathrm{NaCl}$, in $10 \%$ bile, or at $\mathrm{pH} 9.6$. Cells do not survive at $60^{\circ} \mathrm{C}$ for $30 \mathrm{~min}$. Growth occurs only on complex media, but vitamin and amino acid requirements are unknown. Litmus milk is usually reduced, acidified, and clotted. Acid is formed from glucose, lactose, maltose, sucrose, and trehalose. No acid is formed from raffinose, inulin, glycerol, or mannitol. The reaction in sorbitol is variable. Esculin is not hydrolyzed, but some strains hydrolyze salicin. Hippurate is not attacked. Ammonia is formed from arginine. Hyaluronidase is usually produced.

Serological group C. A fibrinolysin for bovine fibrin but not for human fibrin may be produced. Low pathogenicity for mice.

The lactate dehydrogenase is activated by fructose 1,6-diphosphate, but inhibition by phosphate is slight, particularly at pH 5.5 .

The guanine-plus-cytosine content of the DNA is 39 to $40 \mathrm{~mol} \%$ (thermal denaturation method) (7).

DNA-DNA hybridization shows that $S$. dysgalactiae is a distinct cluster with a low relationship to Streptococcus agalactiae, Streptococcus acidominimus, Streptococcus uberis or Streptococcus bovis $(5,6)$. These species all belong to a single cluster, as determined by DNA-ribonucleic acid hybridization (7).

S. dysgalactiae is commonly found in mastitic bovine udders (10), produces mastitis experimentally (8), and may also be isolated from teat skin lesions and bovine vaginas (4).

NCDO 2023 is the type strain. The guanineplus-cytosine content of this strain was estimated to be $39.8 \mathrm{~mol} \%$. Other characteristics agree with the description given above.

\section{LITERATURE CITED}

1. Deibel, R. H., and H. W. Seeley, Jr. 1974. Family II. Streptococcaceae fam. nov., p. 490-517. In R. E. Buchanan and N. E. Gibbons (ed.), Bergey's manual of determinative bacteriology, 8th ed. The Williams \& Wilkins Co., Baltimore.

2. Diernhofer, K. 1932. Aesculinbouillon als holfsmittel fur die differenzierung von euter- und milchstreptokokken bei massenuntersuchungen. Milchwirtsch. Forsch. 13:368374.

3. Edwards, S. J. 1932. Studies on bovine mastitis. VI. The 
non-haemolytic streptococci of bovine mastitis and their relationship to certain saprophytic streptococci from cattle. J. Comp. Pathol. Ther. 45:43-57.

4. Francis, J. 1941. A bacteriological examination of bovine tonsils and vaginas. Vet. J. 97:243-251.

5. Garvie, E. I., and A. J. Bramley. 1979. Streptococcus uberis: an approach to its classification. J. Appl. Bacteriol. 46:295-304.

6. Garvie, E. I., and A. J. Bramley. 1979. Streptococcus bovis: an approach to its classification and its importance as a cause of bovine mastitis. J. Appl. Bacteriol. 46:557566.

7. Garvie, E. I., and J. A. E. Farrow. 1981. Sub-divisions within the genus Streptococcus using deoxyribonucleic acid/ribonucleic acid hybridization. Zentralbl. Bakteriol. Parasitenkd. Infektionskr. Hyg. Abt. 1 Orig. Reihe C 2:299-310

8. Higes, T. M., F. K. Neave, and A. J. Bramley. 1980. Differences in intramammary pathogenicity of four strains of Streptococcus dysgalactiae. J. Med. Microbiol. 13:393-399.

9. Lapage, S. P., P. H. A. Sneath, E. F. Lessel, V. B. D. Skerman, H. P. R. Seeliger, and W. A. Clark (ed.). 1975. International code of nomenclature of bacteria. 1975 Revision. American Society for Microbiology, Washington, D.C.

10. McDonald, T. J., and J. S. McDonald. 1976. Streptococci isolated from bovine intramammary infections. Am. J. Vet. Res. 37:377-381.

11. Plastridge, W. N., and S. E. Hartsell. 1937. Biochemical and serological characteristics of streptococci of bovine origin. J. Infect. Dis. 61:110-121.

12. Schleifer, K. H., and O. Kandler. 1972. Peptidoglycan types of bacterial cell walls and their taxonomic applications. Bacteriol. Rev. 36:407-477.

13. Skerman, V. B. D., V. McGowan, and P. H. A. Sneath (ed.). 1980. Approved lists of bacterial names. Int. J. Syst. Bacteriol. 30:225-420. 